\title{
KOMUNIKASI INTERPERSONAL ANTARA KIAI DAN SANTRI DALAM MENANAMKAN NILAI-NILAI AKHLAKUL KARIMAH DI PONDOK PESANTREN AL- MUSTAQIM BUGEL
}

\author{
Khoirul Muslimin, Khoirul Umam \\ Fakultas Dakwah dan Komunikasi UNISNU Jepara \\ Jalan Taman Siswa (Pekeng) Tahunan, Jepara, Jawa Tengah \\ muslimin@unisnu.ac.id, khoirulumam020295@gmail.com
}

\begin{abstract}
Interpersonal communication is fairly effective in telling, giving opinions or changing a person's behavior, because communication is reciprocal and the response from the communicant can be known directly. The purpose of this study was to determine the interpersonal communication processes and strategies between kiai and santri in instilling moral moral values in the AlMustaqim Islamic Boarding School of Bugel's son. This type is qualitative research with a hermeneutic phenomenology approach. The subjects of this study were kiai, administrators and students of the Islamic Boarding School Al-Mustaqim, the son of Bugel whose samples were taken through a snowball sampling technique. While the object is the process and interpersonal communication strategy. Data collection techniques are carried out by observation, documentation, interviewing and then the data is analyzed by data analysis methods, data reduction, data coding and data analysis. The results of this study are interpersonal communication processes and strategies carried out between kiai and santri in instilling akhlakul karimah values in AlMustaqim Islamic Boarding School in Bugel Village, namely direct communication with two forms of processes, namely the process of interpersonal communication in the session pengajian (through sorogan recitation method in dyadic communication and bandongan in small group communication) and non-recitation interpersonal communication process in (1) Boarding School Management Consultation: (2) Development of santri: (3) Special consultation. And interpersonal communication strategies, namely: (1) Dangled Carrot Strategy: (2) Dependent Sword Strategy.
\end{abstract}

Keywords: Interpersonal Communication, Interpersonal Communication Strategy. 


\begin{abstract}
Abstrak
Komunikasi interpersonal terbilang sangat efektif dalam memberitahu, memberikan pendapat atau mengubah perilaku seseorang, karena komunikasi yang bersifat timbal balik dan dapat diketahui tanggapan dari komunikan secara langsung. Tujuan penelitian ini adalah untuk mengetahui proses dan strategi komunikasi interpersonal antara kiai dan santri dalam menanamkan nilai-nilai akhlakul karimah di Pondok Pesantren Al-Mustaqim putra Bugel. Jenis ini adalah penelitian kualitatif dengan pendekatan fenomenologi hermeneutika. Subyek penelitian ini adalah kiai, pengurus dan santri Pondok Pesantren Al- Mustaqim putra Bugel yang sampelnya diambil melalui tehnik snowball sampling. Sedangkan obyeknya yaitu proses dan strategi komunikasi interpersonal. Tehnik pengumpuan data dilakukan dengan observasi, dokumentasi, wanwacara dan kemudian data tersebut di analisis dengan metode telaah data, reduksi data, koding data dan analisis data. Hasil penelitian ini adalah proses dan strategi komunikasi interpersonal yang dilakukan antara kiai dan santri dalam menanamkan nilai- nilai akhlakul karimah di Pondok Pesantren Al- Mustaqim putra Desa Bugel yaitu secara tatap muka (direct communication) dengan dua bentuk proses, yaitu proses komunikasi interpersonal pada sesi pengajian (melalui metode pengajian sorogan secara dyadic communication dan bandongan secara small group communication) dan proses komunikasi interpersonal non pengajian pada (1) Konsultasi Pengurus Pesantren: (2) Pembinaan santri:(3) Konsultasi khusus. Dan Strategi komunikasi interpersonal yaitu:(1) Strategi Wortel Teruntai:(2) Strategi Pedang Tergantung.
\end{abstract}

Kata Kunci: Komunikasi Interpersonal, Strategi Komunikasi Interpersonal.

\section{A. PENDAHULUAN}

Manusia sangat membutuhkan komunikasi untuk berinteraksi satu dengan lain. Komunikasi merupakan sarana paling utama dalam proses berinteraksi di kehidupan manusia, yang berarti tidak ada seorang pun yang dapat menarik diri dari proses ini, baik dalam fungsinya sebagai mahkluk individu ataupun sebagai mahkluk sosial (Fajrie, 2016:36). Dalam pelaksanaannya, komunikasi dapat terjadi di mana-mana seperti, di sekolahan, pesantren ataupun tempat lainnya. Hal tersebut menandakan bahwa hampir seluruh kegiatan manusia selalu berhubungan dengan komunikasi.

Komunikasi dapat diartikan sebagai proses penyampaian atau pengiriman pesan yang berupa pikiran atau perasaan oleh seseorang untuk memberitahu, merubah sikap, pendapat dan perilaku baik secara langsung maupun tidak langsung, dan yang terpenting dalam proses penyampaian pesan komunikator itu jelas, agar tidak terjadi salah faham. Pesan yang digunakan dalam proses komunikasi juga bisa berupa gagasan, informasi, opini dan berkomunikasi dengan orang lain adalah bentuk yang sangat sederhana (Sapril, 2011:7).

Bentuk kesederhanaan dalam berkomunikasi dapat diketahui dengan adanya dua orang atau lebih saling bertatap muka, berdialog secara bergantian, sehingga terciptalah arah komunikasi secara timbal balik dan akhirnya hasil yang diharapkan oleh komunikator terhadap komunikan baik itu berupa respon positif atau negatif dapat diketahui (Alwi, 2018:1). Dalam berkomunikasi ada beberapa macam bentuk 
komunikasi, di antaranya komunikasi intrapersonal, komunikasi interpersonal, komunikasi kelompok, komunikasi massa, komunikasi organisasi.

Pokok pembahasan dalam penelitian ini yaitu komunikasi interpersonal. Komunikasi Interpersonal ialah bentuk komunikasi yang dilakukan oleh orang-orang secara tatap-muka, yang memungkinkan setiap pesertanya menangkap reaksi orang lain secara langsung, baik secara verbal ataupun nonverbal (Mulyana, 2012:81), sehingga, komunikator dapat mengetahui tanggapan dari komunikan secara langsung apakah komunikasi yang dilakukan itu berhasil atau tidak. Dengan adanya proses timbal balik dan hasil secara langsung, komunikasi interpersonal ini dinilai sangat efektif.

Keefektifan proses komunikasi interpersonal ini dapat diketahui dengan adanya tanda khusus yang terjadi saat proses komunikasi interpersonal dilakukan, yaitu adanya proses arus balik percakapan secara langsung, baik itu verbal dalam bentuk kata ataupun non verbal dalam bentuk bahasa tubuh seperti anggukan, senyuman, mengernyitkan dahi dan lain sebagainya. Dengan begitu, proses komunikasi interpersonal yang terjadi dinilai berhasil dan berjalan secara efektif. bentuk komunikasi interpersonal seperti ini dapat dilakukan oleh siapapun, seperti proses komunikasi yang dilakukan oleh kiai pesantren Al-Mustaqim putra Desa Bugel Kecamatan Kedung Kabupaten Jepara dalam membina santrinya.

Bentuk pembinaan santri melalui proses komunikasi interpersonal sangat penting dilakukan oleh kiai terhadap santrinya. Karena, apabila proses tersebut tidak dilakukan maka, akan terjadi beberapa kegiatan pesantren yang tidak berjalan karena kurangnya pengarahan dari kiai, terjadinya beberapa pelanggaran tata tertib yang di lakukan oleh santri. Hal ini menunjukkan bahwa betapa pentingnya proses komunikasi interpersonal yang dilakukan oleh kiai di Pesantren AlMustaqim putra Desa Bugel Kecamatan Kedung Kabupaten Jepara terhadap santrinya supaya dapat mengkontrol, mengarahkan dan memecahkan masalahmasalah yang dianggap kecil hingga dapat mengakibatkan masalah yang lebih besar.

Kiai merupakan sosok yang paling penting bagi keberadaan pesantren (Huda, 2011:122), selain sebagai pengajar, peran kiai di pesantren sebagai pembina dan pembimbing bagi santri dalam proses belajar mengajar, pemberi motivasi dan pengarah bagi santri yang melanggar peraturan peraturan pondok seperti bolos sekolah, keluar pondok tidakizin, mencuri, berkelahi ataupun lainnya. Adapun kata santri berasal dari kata cantrik (Muhakamuroh, 2014:111), yang berarti orang yang menetap dan mendalami agama islam dengan berguru di suatu tempat dengan sebutan pesantren.

Pesantren merupakan salah satu pendidikan berbasis Islam, dilihat dari fungsinya sebagai tempat pendidikan tradisional, tempat pendalaman, pembelajaran dan pengamalan ajaran agama islam yang menerapkan pentingnya moral keagamaan dengan menanamkan nilai- nilai ahklakul karimah seperti sabar, tolong menolong sesama manusia dan berbaik sangka (Zulqarnain, 2016:4). Pesantren juga dikenal sebagai lembaga 
pendidikan yang mempunyai corak yang khas, yaitu nuansa keagamaan yang kental.

Sebagai lembaga pendidikan keagamaan, Pesantren Al- Mustaqim putra yang terletak di Desa Bugel Kecamatan Kedung Kabupaten Jepara dengan jumlah santrinya 270 santri ini mengajarkan berbagai ilmu-ilmu agama Islam lebih-lebih dalam menanamkan nilai- nilai akhlakul karimah yang peranannya sangat penting supaya dapat membentengi santrinya seiring dengan perubahan zaman. Karena, sekarang ini banyak terjadi berbagai kenakalan remaja di usia pendidikan dan hal tersebut sudah terjadi di berbagai sekolah maupun pesantren, sebagai contoh permasalahan yang terjadi di Pesantren Al- Mustaqim putra seperti, perkelahian antara 2 santri yang terjadi pada tanggal 29 sepetmber 2018 di aula atas pesantren, bolos jam pelajaran sekolah pada tanggal 11 oktober 2018 yang dilakukan oleh 2 santri, dan kasus pacaran antara santri putra dan putri yang berjumlah 14 santri pada tanggal 7 oktober 2018.

Denganadanyaberbagaipermasalahan di pesantren Al-Mustaqim putra Desa Bugel Kecamatan Kedung Kabupaten Jepara ini, diharapkan melalui proses dan strategi komunikasi interpersonal yang dilakukan oleh kiai pesantren Al- Mustaqim dalam rangka mendidik dan membina terhadap santrinya dengan berbagai bermacammacam latar belakang, karakter dan sifat santri yang menempuh pendidikan agama di pesantren tersebut mempunyai akhlak yang baik dan dapat membentengi dirinya sendiri dari perubahan zaman sekarang ini.

Oleh karena itu, peneliti tertarik untuk meneliti bagaimana proses dan straregi yang di lakukan oleh kiai Pesantren AlMustaqim Desa Bugel Kecamatan Kedung Kabupaten Jepara melalui komunikasi interpersonal terhadap santri dalam menanamkan nilai- nilai ahklakul karimah di pesantren tersebut.

\section{B. METODE PENELITIAN}

Pada penelitian kualitatif ini, peneliti menggunakan metode deskriptif adalah suatu metode penelitian yang ditujukan untuk menggambarkan fenomenafenomena yang ada dan terjadi pada saat ini atau saat yang lampau (Sukmadinata, 2015:54).

Jenis pendekatan ini menggunakan pendekatan fenomenologi hermeneutika. Pendekatan ini adalah seni atau metode melihat objek sebagai teks yang menyimpan makna dengan menguak apa yang tersembunyi di baliknya atau metode untuk memahami sebuah realitas sebagaimana adanya dengan pengamatan di lingkungan sekitarnya untuk mendapatkan informasi tentang sesuatu (Sobur, 2014:260). Dalam penelitian ini, peneliti menganalisis dan mempelajari suatu proses komunikasi interpersonal yang dilakukan antara kiai dan santri pesantren Al-Mustaqim Desa Bugel Kecamatan Kedung Kabupaten Jepara dalam menanamkan nilai- nilai ahklakul karimah.

Subyek penelitian ini adalah kiai, pengurus dan santri putra- putri pondok pesantren Al- Mustaqim Bugel Kecamatan Kedung Kabupaten Jepara yang sampelnya diambil melalui tehnik snowball sampling. Sedangkan obyeknya yaitu proses terjadinya komunikasi interpersonal. 
Dalam penelitian ini yang menjadi data primernya adalah hasil wawancara dengan kiai, pengurus dan santri pesantren Al- Mustaqim Desa Bugel Kecamatan Kedung Kabupaten Jepara. Data skunder dalam penelitian ini berupa data tertulis yang berkaitan dengan komunikasi interpersonal, hal ini bertujuan untuk memperkuat hasil penelitian, diantaranya: Jurnal seperti Jurnal Iqro' , Jurnal Humaniora dan Jurnal Wahana Akademika. Skripsi seperti Gaya komunikasi masyarakat Samin di Desa Karang Rowo Kecamatan Undaan Kabupaten Kudus, Komunikasi interpersonal pada tokoh utama film tenggelamnya kapal van derwijk, Studi analisis pola komunikasi interpersonal dalam film surga yang tak dirindukan. Buku seperti Ilmu komunikasi suatu pengantar, Metodologi penelitian kualitatif, Prosedur penelitian suatu pendekatan praktik.

Beberapa metode yang digunakan dalam penelitian ini, yaitu:

\section{Observasi}

Observasi ini dilakukan untuk mendapatkan data tentang komunikasi interpersonal kiai dengan cara mengamati bagaimana proses dan strategi yang dilakukan kiai dalam menanamkan nilai- nilai akhlakul karimah terhadap santri pesantren al-Mustaqim Desa Bugel Kecamatan Kedung Kabupaten Jepara.

\section{Dokumentasi}

Data dokumentasi dalam penelitian ini berupa rekaman suara dan foto yang berfungsi untuk mendapatkan informasi yang berhubungan dengan proses dan strategi komunikasi interpersonal kiai terhadap santri dalam menanamkan nilai- niali akhlakul karimah di pesantren AlMustaqim Desa Bugel Kecamatan Kedung kabupaten Jepara.

3. Wawancara

Dalam penelitian ini, peneliti menggunakan metode wawancara secara mendalam. Jenis wawancara ini tidak terstuktur, karena dengan pertimbangan supaya pertanyaan-pertanyaannya dapat mengarah sesuai kepentingan peneliti. Peneliti mewawancarai beberapa narasumber, diantaranya kiai, pengurus dan santri pesantren Al-Mustaqim Desa Bugel Kecamatan Kedung Kabupaten Jepara. Dan data yang dicari dengan metode wawancara ini adalah proses dan strategi komunikasi interpersonal yang dilakukan oleh kiai terhadap santri dalam menanamkan nilai-nilai akhlakul karimah di pesantren Al-Mustaqim Desa Bugel Kecamatan Kedung Kabupaten Jepara.

Metode analisis data yang digunakan dalam penelitian ini adalah sebagai berikut:

1. Penelaahan seluruh data dari berbagai sumber yang ada yaitu, data hasil dari wawancara, observasi dan dokumentasi.

2. Mereduksi data yaitu dengan merangkum, memilih- milih hal yang pokok, memfokuskan pada hal yang penting, mencari tema dan pola dari data yang terkumpul.

3. Menyusun dalam satuan- satuan (unityzing),kemudiandikategorisasikan. Kategori- kategori itu dilakukan dengan membuat koding.

4. Terakhir yaitu penafsiran data. Dalam penafsiran data ini, peneliti menggunakan metode deskriptif analitik yaitu menganalisis data yang di kumpulkan berupa kata- kata, gambar, 
dan bukan angka, data yang di peroleh darikepustakaan,wawancara,observasi, dan dokumentasi, kemudian data tersebut di analisis dan dideskripsikan sehingga dapat memberikan kejelasan terhadap kenyataan atau realitas secara menyeluruh atas obyek penelitian tersebut (Sudarto, 2002:16).

Tabel 1.1

Alur analisis data

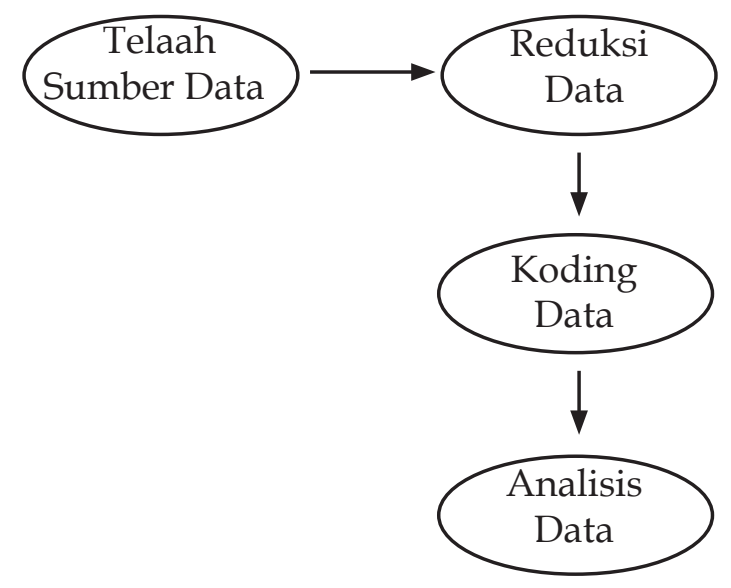

\section{HASIL DAN PEMBAHASAN}

\section{Proses Komunikasi Interpersonal}

Proses komunikasi interpersonal yang berjalan antara kiai dan santri di pondok pesantren Al-Mustaqim Desa Bugel Kecamatan Kedung Kabupaten Jepara merupakan bentuk kegiatan atau sebuah metode yang dijadikan sebagai penunjang dalam proses menanamkan nilai-nilai akhlakul karimah santri.

Proses komunikasi dijalankan kiai untuk membimbing dalam proses penanaman akhlak santri, sehingga santri tersebut mempunyai karakter yang baik, berbudi luhur dan tentunya mempunyai pemikiran yang positif. Dengan acuan proses komunikasi sebagai bentuk merubah, penyampaian pesan, gagasan pikiran dan

Jurnal An-Nida, Vol. 11, No. 1, Januari-Juni 2019 perasaan seseorang dapat diklasifikasikan dalam dua bentuk, diantaranya, proses komunikasi tatap muka (direct communication) dan proses komunikasi bermedia (indirect communication).

Proses komunikasi secara tatap muka (direct communication) dapat diklasifikasikan dalam dua bentuk yaitu:

a. Komunikasi diadik (dyadic communication) ialah sebuah proses komunikasi yang berlangsung antara dua orang dalam situasi tatap muka. Dalam berkomunikasi jenis ini, dilakukan dalam tiga bentuk, yakni percakapan, dialog dan wawancara. Percakapan berlangsung dalam suasana yang bersahabat dan formal. Dialog berlangsung dalam situasi yang lebih intim, lebih dalam, dan lebih personal, sedangkan wawancara sifat nya lebih serius, yakni adanya pihak yang dominan pada posisi bertanya dan yang lainnya posisi menjawab.

b. Komunikasi kelompok kecil (small group communication) ialah proses komunikasi yang berlangsung antara tiga orang atau lebih secara tatap muka, dimana anggota- anggotanya saling berinteraksi satu sama lainnya.

Setelah dilakukannya observasi di Pondok Pesantren Al-Mustaqim Desa Bugel Kecamatan Kedung Kabupaten Jepara mengenai proses komunikasi interpersonal antara kiai dan santri dalam menanamkan nilai-nilai akhlakul karimah ditemukan proses komunikasi interpersonal secara tatap muka (direct communication) dengan dua bentuk proses, yaitu proses komunikasi interpersonal yang dilakukan pada sesi pengajian (dengan jenis komunikasi diadik

ISSN : 2085-3521, E-ISSN : 2548-9054 
dan komunikasi kelompok kecil) dan proses komunikasi interpersonal non pengajian.

a. Proses Komunikasi Interpersonal pada Sesi Pengajian.

Pengajian ini dilaksanakan pada pagi hari setelah sholat subuh berjamaah. Pengajian ini mempelajari kitab yang berisi tentang nilai- nilai akhlakul karimah. Seperti kitab Adab al- 'alim wa al-Muta'allim karya KH. Hasyim Asy'ari, pengajian kitab ini dilakukan saat suasana yang masih segar, karena situasi santri baru bangun pagi dan belum melakukan banyak kegiatan. Waktu seperti ini sangat tepat untuk memberikan nasihat dan pembinaan akhlak santri melalui komunikasi interpersonal dengan metode pengajian sorogan dan bandongan.

1) Pengajian sorogan

Pengajian sorogan yaitu santri mengaji pada kiai secara individual, dengan santri membaca dan menjelaskan isi kitab yang di kaji dan kiai mendengarkannya. Apabila dalam membaca dan mendengarkannya terdapat kekeliruan atau kesalahan, maka kiai akan mengoreksi dan membenarkan kesalahan santri tersebut (Barnawi, 1993:97).

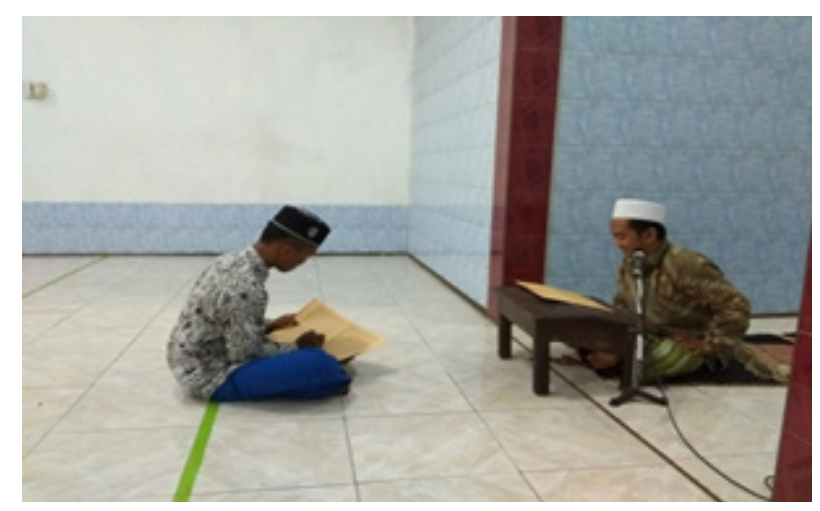

Gambar 1. Pengajian Sorogan antara Kiai dan Santri.

"Cobo kitab iki halaman 29 iki bab ke telu wacanen, di pahami maksute trus di terjemahke", perintah K. Habiburrohman kepada santrinya. Dengan anggukan kepala santri tersebut menjawab" nggeh".

Artinya "Coba kitab ini dengan halaman ke 29 pada bab ke tiga ini di baca, di pahami dan di terjemahkan", Perintah Kiai Habiburrohman kepada salah satu santrinya. Dengan anggukan kepala, santri tersebut menjawab "Ya".

Berdasarkan komunikasi tersebut, proses komunikasi yang dilakukan oleh kiai Habiburrohman dengan santri dalam pengajian sorogan di Pondok Pesantren Al-Mustaqim Desa Bugel Kecamatan Tahunan Kabupaten Jepara yaitu komunikasi interpersonal dengan jenis dyadic communication, karena pada pengajian ini kiai dan santri melakukan proses komunikasi secara tatap muka dan respon dari komunikator yaitu kiai bersifat langsung.

Proses komunikasi interpersonal tersebut kiai Habiburrohman memerintah kepada santri untuk membaca, memahami maksudnya dan menerjemahkannya. Dengan begitu, santri tersebut menjadi komunikator yang aktif, karena dalam metode ini santri membacakan kitab, menjelaskan isi kitab yang sedang di kaji, sementara kiai mendengar dan mengoreksi kesalahan yang ada.

Penggunaan metode pengajian sorogan dengan proses komunikasi interpersonal secara dyadic communication ini dapat dimanfaatkan oleh kiai untuk memberikan pemahaman dan penjelasan isi kitab yang mengarah kepada materi penanaman nilai-nilai akhlakul karimah, seperti akhlak kepada Allah SWT dengan menjalankan semua perintahnya dan 
menjauhi larangannya, akhlak kepada rasulullah saw dengan mengikuti segala tuntunannya dan perintahnya, akhlak kepada keluarga, akhlak terhadap sesama manusia seperti tolong menolong, saling toleransi dan salling menghormati, akhlak terhadap lingkungan dengan melakukan perbuatan, tindakan atau sikap yang bermanfaat.

\section{2) Pengajian bandongan}

Pengajian bandongan yaitu santri mendengarkan seorang kiai yang sedang membaca, menerjemahkan, menerangkan dan seringkali mengulas penjelasanpenjelasan isi kitab. Setiap murid mendengarkan dan memperhatikan kitabnya sendiri-sendiri dan membuat catatan (baik arti maupun keterangan) tentang kata-kata atau penjelasan makna yang sulit (Wahjoetomo, 1997:83).

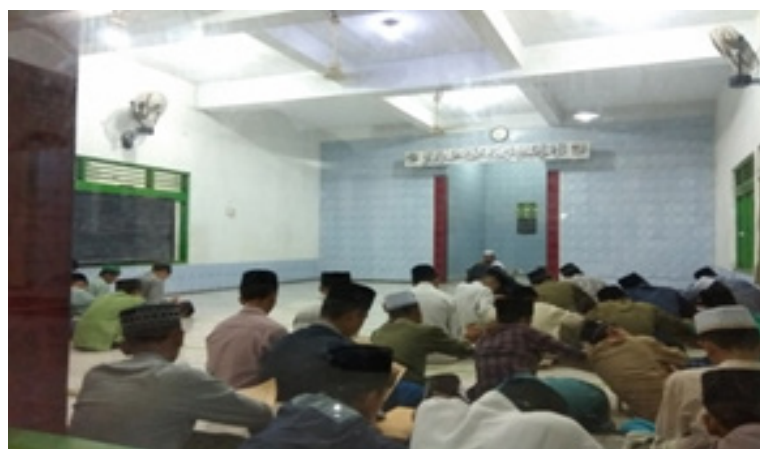

Gambar 2. Pengajian bandongan antara kiai dan santri.

"Neng bab ke telu iki, nok gone kitab Adab al- 'alim wa al- Muta'allim iki diterangake pentinge akhlak seng kudu di dweni santri marang guru ne seng mengko di enggo neng kehidupan nyoto", penjelasan K. Habiburrohman kepada santrinya.
Artinya " di bab ke 3 ini di dalam kitab Adab al- 'alim wa al- Muta'allim ini di terangkan tentang pentingnya akhlak yang harus dimiliki oleh santri dalam menghormati gurunya, dan kemudian di aplikasikan dalam kehidupan nyata" penjelasan K. Habiburrohman kepada santriya.

Berdasarkan komunikasi yang dilakukan oleh kiai Habiburrohman dengan santri dalam pengajian bandongan di Pondok Pesantren Al-Mustaqim Desa Bugel Kecamatan Tahunan Kabupaten Jepara yaitu terjadinya komunikasi interpersonal secara small group communication.

Metode pengajian bandongan ini yaitu sistem pengajian dengan sekelompok murid yang dibimbingan kiai nya secara langsung, sehingga metode ini terbilang sangat efektiv dan kondusif. Karena dengan jumlah santri yang berkelompok ini penjelasan isi kitab dapat menyeluruh kepada para santri.

Proses komunikasi interpersonal secara small group communication ini, kiai Habiburrohman menekankan penjelasan isi kitab yang mengarah kepada materi penanaman nilai- nilai akhlakul karimah, seperti akhlak kepada Allah SWT, akhlak kepada rasulullah saw, akhlak kepada keluarga, akhlak terhadap sesama manusia, akhlak terhadap lingkungan, sehingga dengan adanya penyampaian isi materi akhlak tersebut yang dilakukan melalui proses komunikasi interpersonal antara kiai dan santri diharapkan para santri mempunyai nilai- nilai ahklakul karimah tersebut dan diaplikasikan di dalam kehidupannya, seperti sikap atau perbuatan patuh dalam menjalankan semua perintah, menjauhi larangan Allah SWT, mengikuti 
tuntunandan perintahnya Nabi Muhammad saw, melakukan perbuatan atau sikap yang bermanfaat, tolong menolong, saling toleransi dan tidak saling menghormati.

b. Proses Komunikasi Interpersonal Non Pengajian

Proses komunikasi interpersonal yang terjadi diluar jam pengajian ini berjalan sangat santai dan interaktif, karena ada timbal balik dari pesan yang disampaikan. Proses komunikasi ini biasanya dilakukan terkait dengan permasalahan kehidupan santri di Pondok Pesantren Al- Mustaqim Desa Bugel Kecamatan Tahunan Kabupaten Jepara yang meliputi pembinaan santri yang melanggar peraturan pondok pesantren, hubungan ketua Pondok Pesantren sebagai media untuk berkonsultasi mengenai permasalahan yang terjadi di lingkup pesantren dengan kiai ataupun hubungan santri dengan kiai dalam konsultasi masalah pribadi.

Adapun bentuk proses komunikasi interpersonal yang terjadi di luar pengajian antara lain sebagai berikut:

\section{1) Konsultasi pengurus pesantren}

Komunikasi interpersonal merupakan yang paling efektif dalam mengubah sikap, pendapat dan perilaku seseorang, karena sifatnya yang dialogis berupa percakapan, dengan arus balik yang bersifat langsung. Sehingga komunikator mengetahui secara langsung jawaban atau tanggapaan dari komunikan (Effendy, 2003:30).

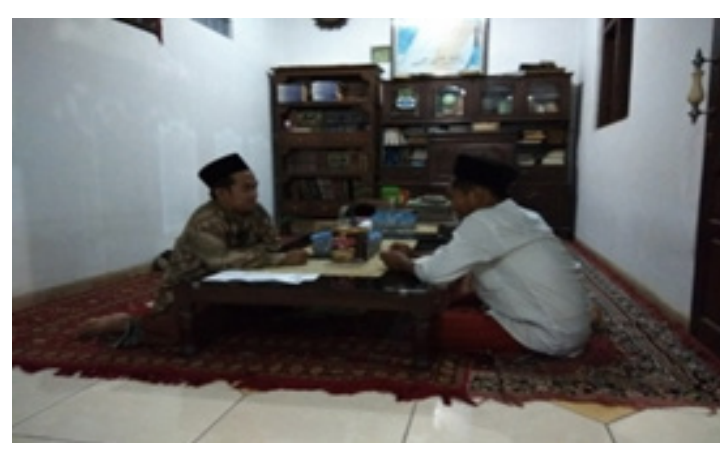

Gambar 3. Komunikasi interpersonal antara Kiai dan Pengurus.

"Pak kiai, badhe nyuwun pengarahane panjenengan tentang pengelolaan pesantren meniko, supados kersane bocah- bocah niku tenang mboten do nakal" Ucap Abdullah Salem. "yo ncen kudune di urusi bocah- bocah kui, kudu sabar, kudu telaten lan ulet anggenmu mernahno bocah- bocah kui supoyo podo orak nakal" jawab K. Habiburrohman seketika .

Artinya "Pak kiai, Saya minta pengarahan dari panjenengan tentang caranya pengelolaan pesantren perihal penataan akhlak santri supaya tidak pada nakal" Ucap Abdullah Salem ketua Pesantren Al- Mustaqim. "Ya memang harus di urusi santri- santri itu, harus sabar, ulet dalam membina santri-santri itu supaya tidak pada nakal" Jawab K. Habiburrohman seketika.

Bentuk proses komunikasi yang terjadi di atas merupakan komunikasi secara interpersonal dengan jenis dyadic communication yang dilakukan oleh kiai Habiburrohman dengan ketua Pengurus Pesantren Abdullah Salem mengenai pesantren dan nilai-nilai akhlak santri. Dalam proses membina santri memang di perlukan keuletan, kesabaran dan pembinan yang serius. 
Pertemuan secara khusus ini membuat Abdullah Salem sebagai ketua Pesantren Al-Mustaqim menjadi lebih nyaman dan dapat mengutarakan apa yang ingin di konsultasikan kepada kiainya secara bebas. seperti meminta pengarahan, saran dan doa.

Konsultasi secara interpersonal ini sangatlah efektif, karena sifatnya yang dua arah, timbal balik secara langsung. Biasanya dalam kondisi secara personal, kiai selalu berpesan kepada ketua pengurus untuk selalu membina para santri supaya mempunyai akhlak yang baik dengan tidak melanggar peraturan pesantren.

\section{2) Pembinaan santri}

Proses komunikasi interpersonal yang terjadi di luar jam pengajian diantaranya adalah ketika terjadi beberapa santri yang mengalami beberapa masalah, seperti ketika santri tersebut melakukan beberapa pelanggaran peraturan-peraturan santri di Pesantren Al- Mustaqim Desa Bugel Kecamatan Kedung Kabupaten Jepara.

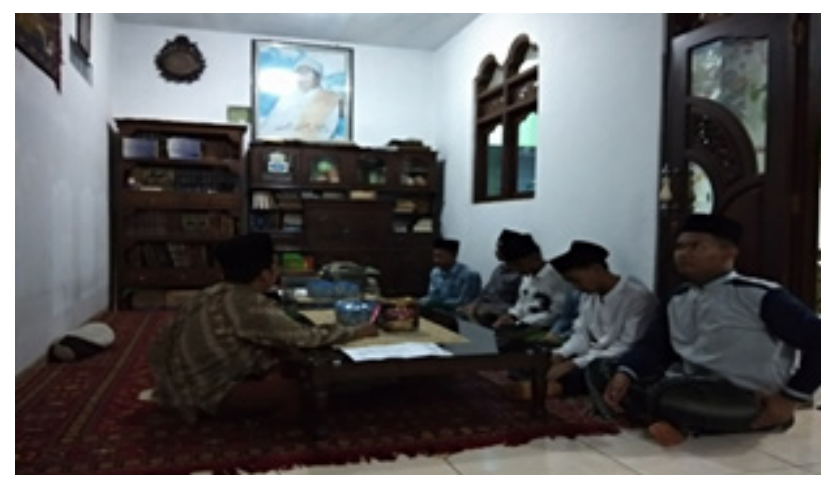

Gambar 4. Pembinaan Santri

"Kabeh santri, aku pesen supoyo podo orak nakal, sinau seng mempeng, mesakke bapak lan ibuk mu oleh e biayai sekolah karo mondok $m u$ " pesen K. Habiburrohman. "Njeh yai"

Jurnal An-Nida, Vol. 11, No. 1, Januari-Juni 2019 jawaban semua santri dengan gaya non verbal anggukan kepala .

Artinya " Kepada semua santri, Saya berpesan kepada kalian semua untuk tidak pada nakal, belajar yang serius, kasihan bapak dan ibuk kalian dalam berkerja untuk biaya mondok dan sekolah kalian semua" pesan kiai Habiburrohman. " Njeh kiai" jawaban semua santri dengan gaya non verbal anggukan kepala.

Berdasarkan proses komunikasi di atas menunjukan terjadinya sebuah proses komunikasi interpersonal secara komunikasi kelompok kecil (small group communication) ialah proses komunikasi yang berlangsung antara tiga orang atau lebih secara tatap muka, dimana anggotaanggotanya saling berinteraksi satu sama lainnya.

Pembinaan santri ini dilakukan di rumah Pengasuh Pesantren AlMustaqim, pertemuan ini terjadi ketika Pengurus Pesantren sudah tak dapat lagi menangani santri tersebut, sehingga di temukan dengan kiai pesantren dengan harapan diberi beberapa pengarahan mengenai permasalahan tersebut. Dalam proses pembinaan santri tersebut, kiai Habiburrohman berpesan kepada semua santri untuk tidak mengulangi kesalahan yang terjadi, kiai juga mengiangatkan kepada semua santri betapa sulitnya orang tua mencari uang untuk biaya pondok pesantren dan biaya sekolah.

Proses komunikasi ini sangat efektif terhadap santri yang bermasalah. Karena dengan proses komunikasi interpersonal secara timbal balik, dua arah dan kiai dapat menilai bahwa komunikasi yang dilakukannya berjalan efektif dan 
pengarahan dari kiai dapat diterima oleh santri tersebut. Dengan bukti adanaya respon komunikasi secara verbal maupun non verbal seperti anggukan kepala ataupun lainnya dapat diketahui.

3) Bimbingan konseling

Pada beberapa santri melakukan pertemuan dengan kiainya secara khusus, karena dengan proses komunikasi secara interpersonal ini membuat beberapa santri dapat mengutarakan apa yang ingin di konsultasikan kepada kiainya, seperti meminta pengarahan, saran ataupun doa.

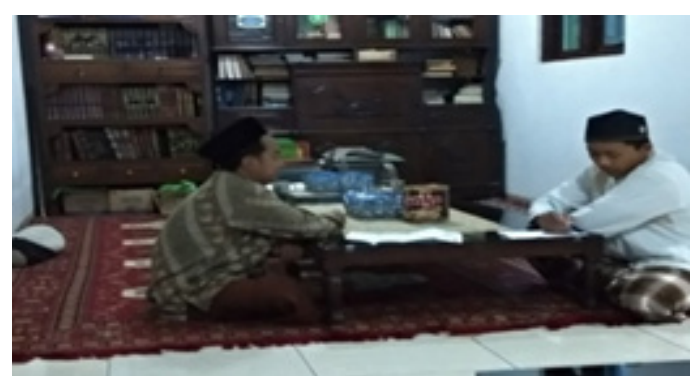

Gambar 5. Bimbingan konseling.

"Pak kiai, badhe nyuwun ijen ajeng ngawontenaken penelitian skripsi ten pesantren e njenengan kaleh ajeng tangklettangklet gegayutan kalian pembinaan akhlak murid" tanya peneliti tersebut. "nggeh rak po po, soal pembinaan akhlak bocah kui ncen kudune di bimbing, di arahno kelawan perkoro seng bener lan di paringi contoh seng bener, sehinggo dadi tauladan seng apik" jawab Kiai Habiburrohman.

Artinya "Pak Kiai, minta izin untuk melakukan penelitian skripsi di pesantrennya njenengan, dan sekalian tanya- tanya tentang caranya pembinaan akhlak santri yang benar" tanya peneliti tersebut. "Ya tidak apa- apa melakukan penelitian skripsi di pesantren saya, untuk masalah pembinaan akhlak murid memang harusnya ada proses pembimbingan, di arahkan kepada sesuatu yang benar dan di beri contoh perilaku yang benar, sehingga menjadi tauladan yang baik" jawab Kiai Habiburrohman.

Berdasarkan proses komunikasi yang dilakukan oleh kiai Habiburrohman dengan salah satu santrinya dalam meminta izin melakukan penelitian skripsi di pesantren beliau dan melakukan proses interview tentang proses pembinaan akhlak santri supaya mempunyai akhlak yang baik yaitu komunikasi interpersonal dengan jenis dyadic communication.

Kiai Habiburrohman memberikan penjelasan bahwa dalam mendidik murid itu memang di butuhkan proses pembimbingan, di arahkan kepada sesuatu yang benar dan di beri contoh perilaku yang benar, sehingga menjadi tauladan yang baik.

Oleh karena itu, dapat diketahui bahwa proses bimbingan konseling secara komunikasi interpersonal ini sangatlah efektif, karena sifatnya yang dua arah, timbal balik secara langsung, kondisi santai, nyaman dan tujuan konsultasi dari santri tersebut dapat tersampaikan, sehingga permasalahan yang terdapat pada santri tersebut dapat terselasaikan.

\section{Strategi Komunikasi Interpersonal}

Muhammad Budyatna dan Leila Mona Ganiem dalam bukunya "Teori Komunikasi Antarpribadi" menyatakan bahwa untuk menghasilkan respon yang efektif, baik dan umpan balik yang berdampak positif dari komunikan, maka di butuhkan beberpa strategi-strategi kendali komunikasi supaya keinginan yang diharapkan oleh 
komunikator dapat tercapai maksimal, yaitu :

a. Strategi Wortel Teruntai

Strategi wortel teruntai atau danling carrot strategies strategi dalam bentuk pemberian imbalan atau hadiah yang dilakukan oleh komunikator terhadap komunikan apabila komunikan melakukan tindakan yang diharapkan oleh komunikator.

b. Strategi Pedang Tergantung

Stategi pedang tergantung atau hanging sword strategies yaitu strategi ini digunakan oleh komunikator terhadap komunikan untuk mengurangi probabilitas respon yang tidak diinginkan.

c. Strategi Katalisator

Strategi katalisator atau catalyst control strategies yaitu strategi yang dilakukan oleh komunikator untuk memancing atau memicu komunikan supaya respon yang diharapkan oleh komunikator dapat tercapai dengan tidak memberikan imbalan atau memberikan hukuman.

d. Strategi Kembar Siam

Strategi kembar siam atau siamese twin strategies yaitu strategi yang digunakan terhadap hubungan yang sudah terbentuk dengan baik antara komunikator dengan cara mereka selalu bersama-sama. Karena adanya ketergantungan satu sama lain untuk mendapatkan kepuasan pribadi.

e. Strategi Dunia Khayal

Strategi dunia khayal fairyland strategies yaitu strategi kendali yang memberikan semacam ketenangan dari perasaan cemas, tetapi memiliki dasar realitas yang tidak seberapa dan tidak

Jurnal An-Nida, Vol. 11, No. 1, Januari-Juni 2019 cukup untuk menggantikan kendali yang sebenarnya.

Berdasarkan observasi yang dilakukan di Pondok Pesantren Al-Mustaqim Desa Bugel mengenai komunikasi interpersonal antara kiai dan santri ditemukan beberapa strategi komunikasi interpersonal yang dilakukan oleh kiai Habiburrohman dalam menanamkan nilai-nilai ahklakul karimah di Pondok Pesantren Al-Mustaqim Desa Bugel yang terdapat dalam dua bentuk proses kegiatan yaitu:

a. Pembimbingan santri

Penerapan strategi wortel teruntai atau danling carrot strategies ini supaya untuk melakukan sesuatu yang komunikator inginkan apabila orang itu dapat menikmati, memperoleh untung dan terhibur oleh pemberian itu, dan tujuan dari strategi ini.

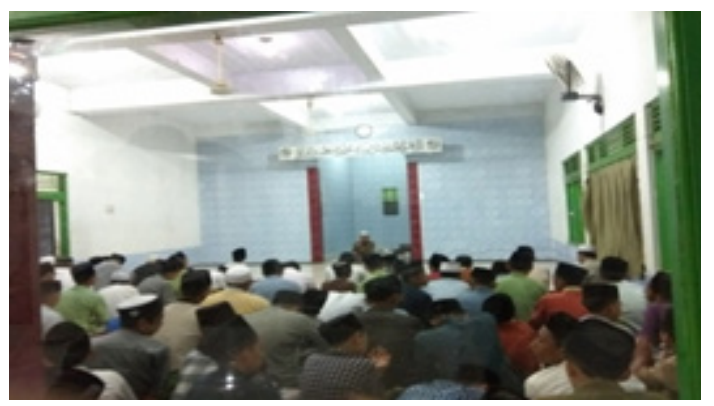

Gambar 6. Pelaksanaan Strategi Wortel Teruntai

"Cah santri kudune duweni sikap akhlak seng sae, hasil ngaji akhlak e kudune di laksaake nok gone kehidupan nyatane. semono ugo kudune semangat anggene belajar, soale iki dino ngadepi tes supoyo entuk hasil seng apek, paham ra.?" Ucap K. Habiburrohman. Secara bersamaan semua santri menjawab "Nggeh".

Artinya "Santri itu harus mempunyai sikap akhlak yang bagus, hasil belajar kitab akhlak harus di aplikasikan dalam 
di kehidupan. Begitu juga santri harus semangat dalam kegiatan belajar karena mengahadapi tes, semoga dari belajar tersebut mendapat hasil yang bagus, semua paham. ? ucap K. Habiburrohman. Secara bersamaan semua santri menjawab "Ya".

Berdasarkan kegiatan pembimbingan santri dengan strategi komunikasi interpersonal yang dilakukan oleh Kiai Habiburrohman dalam menanamkan nilainilai akhlakul karimah santri di Pondok Pesantren Al-Mustaqim Desa Bugel Kecamatan Tahunan Kabupaten Jepara yaitu menggunakan strategi wortel teruntai atau danling carrot strategies.

Strategi ini diasumsikan bahwa kiai dapat meningkatkan probabilitas untuk memperoleh respon yang diingkan apabila kiai memberikan kepada santri imbalan. Penerapan strategi wortel teruntai atau danling carrot strategies di Pondok Pesantren Al- Mustaqim ini seperti ketika santri mulai kurang kondusif dalam belajar di pesantren tersebut ataupun bentuk tindakan persuasif, maka kiai Habiburohman langsung memberikan stimulasi supaya para santri mulai semangat kembali. Stimulasi yang diberikan berupa pembinaan, bimbingan, motivasi dan nasehat supaya para santri belajarnya ditingkatkan kembali.

b. Pemberian sanksi

Stategi pedang tergantung atau hanging sword strategies yaitu strategi ini digunakan oleh komunikator terhadap komunikan untuk mengurangi probabilitas respon yang tidak diinginkan. Strategi ini merupakan bentuk hukuman.

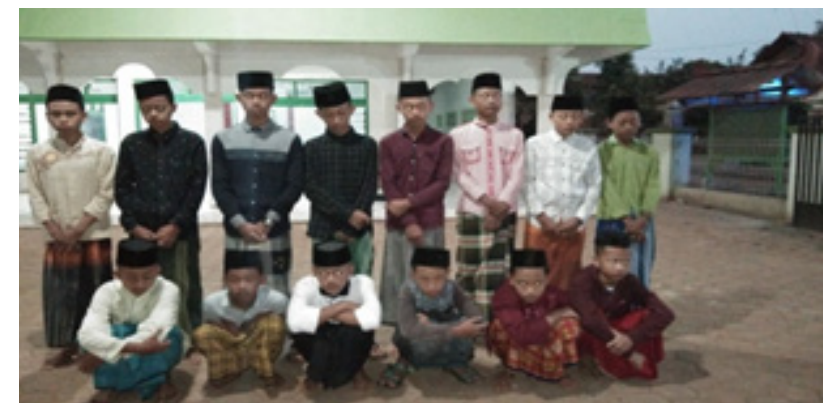

\section{Gambar 7. Hukuman dengan Strategi Pedang Tergantung}

"Kabeh santri, aku pesen supoyo podo orak nglanggar peraturan Pondok Pesantren yen koe kabeh pengen dadi santri seng apek, ojo nakal, sinau seng mempeng, mesakke bapak lan ibuk mu oleh e biayai sekolah karo mondok $m u$ " pesen K. Habiburrohman. "Njeh yai" jawaban semua santri dengan gaya non verbal anggukan kepala.

Artinya " Kepada semua santri, Saya berpesan kepada kalian semua supaya tidak melanggar peraturan Pondok Pesantren Lagi, jika memang kalian semua ingin menjadi santri yang baik. Jangan nakal, belajar yang serius, kasihan bapak dan ibuk kalian dalam berkerja untuk biaya mondok dan sekolah kalian semua" pesan kiai Habiburrohman. "Njeh kiai" jawaban semua santri dengan gaya non verbal anggukan kepala.

Berdasarkan hasil analisis terhadap proses pemberian sanksi dengan strategi komunikasi interpersonal yang dilakukan oleh kiai Habiburrohman dalam menanamkan nilai- nilai akhlakul karimah santri di Pondok Pesantren Al- Mustaqim Desa Bugel Kecamatan Tahunan Kabupaten Jepara yaitu menggunakan strategi pedang tergantung atau hanging sword strategies. 
Penerapan stategi pedang tergantung atau hanging sword strategies di pondok pesantren Al-Mustaqim Desa Bugel Kecamatan Tahunan Kabupaten Jepara ketika santri tersebut melanggar beberapa peraturan pondok pesantren, sehingga kiai habiburrohman memberikan hukuman sesuai panduan yang terdapat di peraturan pondok pesantren Al- Mustaqim diantaranya adalah di hukum berdiri di halaman pesantren, membersihkan halaman pondok, membersihkan kamar mandi pesantren atau pun sebagainya. Dengan adanya penerapan stategi pedang tergantung yang dilakukan di Pondok Pesantren Al-Mustaqim Desa Bugel Kecamatan Tahunan Kabupaten Jepara menjadi lebih kondusif dan belajar santripun menjadi tenang. Karena tujuan dari adanya strategi ini adalah mengurangi atau membatasi perilaku-perilaku yang tidak sesuai dengan peraturan dasar pesantren dengan cara memberikan hukuman bagi yang melanggarnya.

\section{SIMPULAN}

Proses komunikasi interpersonal yang dilakukan antara kiai dan santri dalam menanamkan nilai- nilai akhlakul karimah di Pondok Pesantren Al- Mustaqim Desa Bugel Kecamatan Kedung Kabupaten Jepara yaitu komunikasi interpersonal secara tatap muka (direct communication) dengan dua bentuk proses, yaitu proses komunikasi interpersonal yang dilakukan pada sesi pengajian (dengan jenis komunikasi diadik dan komunikasi kelompok kecil) dan proses komunikasi interpersonal non pengajian.

1. Proses Komunikasi Interpersonal pada Sesi Pengajian.

Proses komunikasi interpersonal pada sesi pengajian yang dilakukan antara kiai dan santri dalam menanamkan nilai- nilai akhlakul karimah di Pondok Pesantren Al-Mustaqim Desa Bugel Kecamatan Kedung Kabupaten Jepara yaitu melalui metode pengajian sorogan secara dyadic communication dan bandongan secara small group communication.

2. Proses Komunikasi Interpersonal Non Pengajian

Proses komunikasi interpersonal yang terjadi diluar jam pengajian ini berjalan sangat santai dan interaktif, karena ada timbal balik dari pesan yang disampaikan, diantaranya yaitu: (1) konsultasi pengurus pesantren; (2) pembinaan santri; dan (3) Konsultasi khusus.

Strategi komunikasi interpersonal yang dilakukan oleh kiai Habiburrohman dalam menanamkan nilai-nilai ahklakul karimah di Pondok Pesantren Al- Mustaqim 
Desa Bugel Kecamatan Kedung Kabupaten Jepara supaya menghasilkan respon yang efektif, umpan balik yang berdampak positif dari santri, yaitu: (1) strategi wortel teruntai; dan (2) strategi pedang tergantung.

\section{DAFTAR PUSTAKA}

Alwi, M. Zanuar Rohman, "Gaya Komunikasi Masyarakat Samin Di Desa Karangrowo Kecamatan Undaan Kabupaten Kudus “, Skripsi Unisnu Jepara, Jepara : Fakultas Dakwah Dan Komunikasi, 2018.

Banawi, Imam, Tradisionalisme dalam Pendidikan Islam, Surabaya: AlIkhlas, 1993.

Fajrie, Mahfudlah, “Budaya Komunikasi Warga Madura ( Budaya Komunitas Profesi Pangkas Rambut Madura di Kecamatan Tahunan Kabupaten Jepara)", Wahana Akademika, 03, 01, April, 2016, Semarang: UIN Walisongo Semarang, 2016.

Huda, M. Syamsul, " Kultus Kiai: Sketsa Tradisi Pesantren ",Teosofi, 1, 1, Juli, 2011, Surabaya: Fak. Ushuluddin IAIN Sunan Ampel, 2011.

J. Moleong, Lexy, Metodologi Penelitian Kualitatif, Edisi Revisi, Bandung: PT. Remaja Rosdakarya, 2012.

Muhakamurroh, Ahmad " Pesantren:Santri, Kiai dan Tradisi “, $I b d a$ ', 12, 2, JuliDesember 2014, Mesir: Universitas Al- Azhar, 2014.

Mulyana, Deddy, Ilmu Komunikasi Suatu Pengantar, Bandung: PT. Remaja Rosdakarya, 2012.

Sapril, "Komunikasi Interpersonal Pustakawan", Iqro', 05, 01, Mei, 2011, Solo: IAIN Surakarta, 2011.

Sobur, Alex , Filsafat Komunikasi, Tradisi dan Metode Fenomenologi, Bandung: PT. Remaja Rosdakarya, 2014.

Sudarto, Metodologi Penelitian filsafat, Jakarta: PT. Raja Grafindo Persada, 2002. 
Sukmadinata, Nana Syaodih, Metode Penelitian Pendidikan, Bandung: PT. Remaja Rosdakarya, 2015.

Wahjoetomo, Perguruan Tinggi Pesantren: Pendidikan Alternatif Masa Depan, Jakarta: Gema Insani, 1997.

Zulqarnaen, Wildan, " Komunikasi Antarpribadi Ustadz dan Santri Dalam Pembentukan Karakter Santri ", Skripsi : UIN Syarif Hidayatullah Jakarta, Jakarta : Fakultas Ilmu Dakwah Dan Ilmu Komunikasi, 2016. 